Regional and Business Studies (2020) Vol 12 No 2, 47-63

Szent István University Kaposvár Campus, Faculty of Economic Science, Kaposvár doi: $10.33568 /$ rbs.2519

\title{
Analysis of Organizational Excellence Based on INDEPENDENT Key INDICATORS AMONG HuNGARIAN SME LEADERS
}

\author{
Erzsébet Gyopár CsAPAI, Szilárd BERKE \\ Szent István University Kaposvár Campus, H-7400 Kaposvár, Guba Sándor u. 40.
}

\section{ABSTRACT}

Excellence and success are those questions, which could hardly be held or clarified because there are exceptionally subjective and complex correlations behind the definitions. In specific literature we could see that success could be defined in many ways, but there is not any index number or formula that anyone could determine easily and according to that, "label" the companies. The conventional performancelexcellence measuring methods are based on the financial indices, but we had a plan to measure other indicators. Therefore, we asked questions about the market share, size of the company, growth rate, export activities, efficiency, and the amount of turnover, awards, prominence lists, years of experience as a leader, quality of abilities as a leader. The number of the incoming questionnaires was 148 from Hungary (CEO-s and leading managers from the highest positions). Our results shows that the chosen variables to measure the organizational excellence as awards and appreciations, export activity, TOP-listing and market influence has impact on organizational excellence, so we can conclude that in the performance measurement systems it is important to include the "non numeric financial" indicators, too. Based on the correlations between the indicators and the organizational excellence we can conclude that in line with the company size, the chance rises to be awarded, the number of employees influences the chance to appear on prominence lists, and also affects the strength of the market position. Regarding the personal leadership we can establish that the micro-and small-sized enterprises have got real backwardness in the field of management in proportion to the multinational companies, and the self-assessment of the leaders is still rather low.

Keywords: organizational behavior, leadership, effectiveness

Jel codes: M12, M14, M54

\section{INTRODUCTION}

For a long time, the corporate performance was measured by financial indicators (see (Getz \& Carlsen, 2000; Howard, 2006) and the growth in terms of income (Walker o Brown, 2004). In the Hungarian literature we can find these topics in the work of (Bódi-Schubert, 2012; Chikán \& Czakó, 2009 and Kerepesi, 2009) pointing out that the goal is also influenced by funding efforts. According to the study of the GKI economic researcher (Némethné Pál \& Papanek, 2014) the goals can be written down by financial indicators as increasing income, decreasing costs, increasing profit, increasing market share and corporate value. According to Cole (2017) the success is not only the accomplishment. 
At the same time success has external factors, too. Based on the research of GKI (Némethné Pál \& Papanek, 2014), the factors explaining success include labor and capital as necessary resources; the improvement of performance created by labor division (Ridley, 2012) and the competitive impact (Porter, 2006). There are also other types of grouping, as listed on the World Competitiveness Yearbook (IMD, 2012), where the external factors are: economic power, government efficiency, business efficiency and the infrastructural level.

According to Neely et al. (1995), the efficiency or effectiveness means meeting company goals, and the economy means the efficacy of the use of resources required to achieve the objectives. Cho and Dansereu (2010) say that organizational performance refers to the achievement of goals and objectives, and Tomal and Jones (2015) regard the organizational results or outputs as organizational performance. Similarly to international literature, the Hungarian sources, like Böcskei and Fekete (2012) link the corporate performance to three elements: efficacy, efficiency and the relationship between the tools used and the results achieved, while Szüts (1983) examines corporate efficiency from quantitative and qualitative perspectives. On the quantitative side, it shows the result-expenditure ratio, while on the qualitative side it shows the realization of the goal. Dobák (2008) links the effectiveness of the organization to the realization of the organization's goals and the organizational efficiency to the achievement of the objectives. The decisive role of the leadership is also unquestionable in the efficiency of the organization (Bakacsi, 2019; Kollár \& Szabó, 2019; Pierog et al., 2017; Kömüves et al., 2018) and it is closely related to other factors not discussed in this article, such as human resource management (Dajnoki \& István, 2020; Pató \& Illés, 2018). In general, organizational growth processes result from a cycle of three main processes: corporate planning, strategy implementation and performance measurement or evaluation (David, 2011).

According to the classical approach, in order to know how my company, my organization is performing, to be able to see how it is moving towards excellence, performance measurement is a must. „The performance measurement is part of the corporate control process. The goal of the corporate measurement is the evaluation and continuous monitoring of the efficiency and efficacy of the company operations. In the frame of the plan-do-check-act cycle, the measurement provides feedback, signals for any intervention that may be needed and information to support decisions at both, strategical and implementation levels.

The method of the measurement can significantly affect the company's operations and the development of the performance. Performance measurement cannot only provide information to help decisions, but also directly influence decisions, the actions of stakeholders (company managers, employees) who try to influence the development of the factors focused on the performance measurement system. At the same time, an inappropriate yardstick can also encourage you to act against your goals" (Wimmer, 2002).

During the research we have repeatedly faced the question of how to measure the performance of a company, how we can know whether a company or enterprise 
is performing well or excellently. In order to develop a performance measurement system, it is necessary to determine the key factors. According to Lorino and Gehrke (2007), only corporate performance that contributes to the achievement of strategic goals or contributes to the improvement of value/cost ratio can be considered.

Atkinson (1988) formulates it in this way: „Strategical performance measurement determines the purpose and focus of managerial accounting. Strategical performance measurement begins with the owners of the organization by defining their primary goals. The organization's designers conduct strategical planning exercises to learn how they will pursue the organization's primary goals. The chosen strategic plan is the result of a quantity of formal and informal concluded contracts between the organization and stakeholders. The sale and purchase between the organization and its critical stakeholders determines the secondary objectives of the organization. The importance of the secondary goals varies depending on their impact on the achievement of primary goals. Secondary goals are critical, because they are variants used by the employees of the organization to achieve success - defined as the desired performance in the organization's primary goal. As the employees monitor the level of achievement of the primary and secondary goals, the data obtained can be used by them to review their perceptions of the organization's primary and secondary goals, which is an organizational learning process. The last step in the strategic performance measurement is to link incentive payments to performance measurement results".

Gates (1999) based on a research which involved 113 companies stated: "The strategic performance measurement systems turn the business strategies into achievable results. The financial, strategic and operational measures can be combined to measure how well a company can meet its goals".

Based on Neely's (1998 then 2004) opinion, the measurement systems help the decision preparation, because they make efficiency and effectiveness measurable. Ittner at al. (2003) who surveyed financial service provider firms, state that strategic performance measurement systems provide information that identifies a firm's strategies, providing the best opportunities to achieve the firm's goals and align management processes with the achievement of selected strategic goals.

As we can see, the performance measurement systems are very different, but they have one common property: the results depend based on the extent the objectives, strategies, processes, activities and the evaluation of results are clearly defined. For this reason, we considered it necessary to include in the primary research a strategic model that could be adapted to the topic of managerial thinking. That is how the choice fell to Sinek's (2019) model and at the value-creating processes (functions) level to certain elements of Kapferer and Porter's (2008) value-chain model.

Zsidó and Fenyves (2015) divided the performance measurement systems into two groups: traditional and reusable ones. Traditional performance measurement systems are based on the strategy, objectives and methods used and are expressed in financial indicators. The most common ones are:

- Profitability indicators, which measure the ability of companies to generate income, how they can generate income from sales, assets, and capital. 
- Efficiency indicators, which measure how the companies can generate income with their assets.

- Financial indicators that show the financial position of a company.

The idea of "new" performance measurement methods starts with Kaplan and Johnson (1987) who indicated that the traditional financial indicators could not show the change generated by the competitive market and the modern organization's strategy. In addition to past financial information, according to Rappaport (1983 then 1999), the future also must be considered in terms of what the company will be able to accomplish in the future. In the 1980s, theories were born and empirical research addressed to the survival and to the long-term success of companies, concluding that the results were not only caused by the increase of the shareholder value. Based on Donaldson and Preston's (1995) "stakeholder" theory, in addition to the input-output model, any person or group, who has a legitimate interest and based on that participates in the firm willing to achieve some kind of profit, at the same time creates value, because the process is bilateral, having back and forth effect. In this way, they have an impact on corporate profitability.

\section{MATERIALS AND METHODS}

Excellence and success are those questions, which could hardly be held or clarified because there are exceptionally subjective and complex correlations behind the definitions. In the literature we could see that success could be defined in many ways, but there is not any index number or formula that anyone could determine easily and according to that, "label" the companies. The everlasting dilemma appears between the accounting approach and the financial result. Both are based on that the financial results determine the successfulness, but the subject of the debate between the two approaches is the question of the value of time. It means that: Is it possible to draw any conclusion according to the former accountancy numbers or should we correct it with the time-factors? The modern times profession expands it with the organizational behavior. Because of these, the question arises how to measure it. What kind of key factors could influence the corporate performance and what kind of value should they have to say to an organization that it is excellent? The conventional performance measuring methods are based on the financial indices, whereas the new methods are complemented with the strategic goals, the fulfilment of the goals and the changes, which are generated by the competitive market.

From this approach we planned to distinguish the actions determining excellence from those already achieved activities which highlight the company from the others. These are: awarding, belonging to the TOP 100 or TOP 500 companies and we took the export activity, as a measuring index, because we think that a successful challenge at the export competitive market is an eminent result criterion. Besides these, we asked questions about the market share, growth rate, efficiency and the amount of turnover to confirm or disprove the statements. Self-declaration elements were also included among the human factors, such as: the participant's self-assessment of how 
good/excellent the leader is, and whether the organization that he/she manages is a market leader or not, and what the growth rate of the organization is in the market.

The market research was conducted by a research-group of Kaposvár University with the title "Leadership practice in small and medium-sized enterprises and startups - success-thinking and marketing strategy decisions" within the scope of the EFOP-3.6.1-16-2016-00007 NK2 project. It was supported by the Intelligent Specialization Program at Kaposvár University, and was entitled „Excellence in Leadership and Management” and „Humanagement - Human Value” research groups as founders of the Leader's Habits Network (leadershabits.com).

The aim of the research was to reveal a general survey, to establish a 'diagnosis', which could be later a base for a national research. Because of this neither randomness nor representativeness was our goal and qualitative research was counted nearly with the same importance in the evaluation of the results as the quantitative procedure. The chosen topic is many-sided, with extraordinary complex and diversified components. The whole research had an exploration 'pilot' character because we did not find any validated questionnaire in the chosen context that analysed all the designated dimensions (Berke, 2019). Our target was - in general - the senior managers: not only "the excellent" ones but also all of them who are leaders of an organization and lead themselves and/or a smaller-bigger community, manage different processes and are responsible for the results. The fundamental question for this article is the following: Is there any connection between the organization's leader's excellence (awards, growth rate, etc.) and the organization size and the number of the employees? And: How do the objective, external measurement elements (for example TOP-list's participations, awards, growth rate, etc.) appear as the final result of managerial work?

In the frame of the project there were two-step examinations. On one hand, there was a chain of focus group interviews, which was conducted among the Hungarian entrepreneurs. On the other hand, there was a questionnaire. The quantitative examinations took place after the qualitative examination. We asked company leaders, senior leaders to fill in our questionnaire. It was not random, nor representative, because it was hard to reach and mobilize the senior leaders and owners in favour of the research. Neither the research plan included this as an expectation because we knew that this special target group could be reached with difficulty and because of the unrevealed character of the target area of the research. We tried to send the questionnaire to more address-lists, for example to the list of the Chamber of Industry and Agriculture with the support of HSZOSZ or to the list of the local organizations of BNI but the respondent-willingness was almost immensely low, although we extended the period of the retrieving phase. As the questionnaire did not appear among the undertaken mandatory tasks, it appeared only in the research plan, the main results were phrased by the research group based on the focus group interviews.

We made the managerial questionnaire in Google Forms based on partially the processed focus group interviews, partially the results found in professional literature and international practice and partially the first version of the research group's questionnaire. The questionnaire contained 45 questions, closed and opened types equally, and also the so-called confidential ones, too. 
In the examination 148 people could be involved, partially because of the low availability and respondent willingness and partially maybe because of the confidential characteristic of the questions and the big extent of the questionnaire (it needed circa 25-30 minutes to fill in). We wanted to analyse a complex economic/corporate problem with the help of the survey. Because of it we used a variance- (PLS) based modelling (Kemény, 2015.), not the probability sample purchasing, the arbitrary (send to a pre-arranged address-list) or the expert (judging sampling) one (Majoros, 2010). In this case the minimum number of the elements are between 30-130, according to literature. "Because of the problematic target group or research circumstances, that sample, which minimum consists of 60-70 elements, could be acceptable," said (Lázár, 2009.). Bányai and Sipos (2019) named similar problems from the field of the academic examinations. In their case the number of the base-multiplicity was 916, but they could realize only 103 appraisable answers after a more-step approach/promotion. The GDPR regulation, which was promulgated in May 2018, raised the number of difficulties.

We evaluated the data in groups with statistical methodology, based on personal features of the respondent leaders and the parameters of the organizations. We analysed the questions of the questionnaire with arithmetic mean, distribution coefficient and organizing the answers into groups depending on their nature. We used SPSS program for the analysis.

\section{RESULTS AND THEIR ASSESSMENTS}

Half of the organizations which were involved in the examination, could be found in the service industry; $16.9 \%$ of them in the public sector. Other industries were represented: manufacturing industry, commerce etc. The regional distribution was the following: the biggest rates were from Southern-Transdanubia (35.1\%) and Central-Hungary (31.9\%) but Southern Great Plain (16.9\%) and Western-Transdanubia (10.1\%) were also represented, as well as three more regions with smaller rate. By the age of the companies they were represented as follows: the young companies, under 5 years old (23.6\%), 11-20 years old companies (23.6\%) and the 21-30 year old companies (22.3\%), so the distribution of the different ages was similar to each other. The distribution of the number of the employees are the followings: $45.3 \%$ are between $0-9$ people, $21.6 \%$ are between 10-49 people and $8.1 \%$ are between $50-249$ people, but in smaller rate those companies were also represented, which had more employees. In the aspect of the amount of the turnover, the companies were represented to over 10 billion HUF, at a larger rate there were those companies, who had 10-50 million HUF per year (19.6\%), under 5 million HUF per year (16.2\%), over 10 billion HUF per year (14.9\%) and between 50-100 million HUF per year (12.8\%). We made a classification based on the growth rate: the majority had adequate growing (43.2\%), and similar rate had the stagnant ones (25\%) and the prominent growing ones (24.3\%). 77 percent of them are profitable.

According to the SMEs categories, there were decisively microenterprises (45.3\%) and small sized enterprises (37.2\%). Half of them were family businesses, but with a very small rate the start-up companies (14.9\%) were also represented. $61.5 \%$ of the represen- 
ted companies do not have any export activities; 12,9 percent of them are on a TOP-list and according to the growth-rate, 64,9 percent of them increased in the last year.

\section{The applied independent (market) key performance indicators for the measure- ment of organizational excellence and their assessments}

For the measurement of organizational prominence, we applied the following key performance indicators (value indicators), supposing that these were adequately objective and capable of distinguishing those who perform better, from those who perform on the average. These were: placement on a "TOP-list" (prominence list); awards and appreciations; export activity; the trend of the leading position on the market and the market growth rate. The majority of these examine the results inherently from a financial point of view, and this question group had high priority. In case of that if there was anyone between the organizations from the sample who performed well on these independent challenges, then we could take the opportunity to analyse the connections with the human factors focusing on those who performed eminently well.

\section{Awards, appreciations}

We asked the question: Did the organization win any awards in the last 5 years? From the 148 respondents 102 (68.9\%) did not have any awards, so 46 respondents $(31.1 \%)$ received some kind of award. During the analysis we examined the connection between all the unobserved latent variables. We found significant correlation in functions of the SME categories, the age of the company and the amount of the turnover. Table 1 contains the results.

Conclusions:

- Depending on the number of employees the rate of the awarded companies is increasing, but not proportionally.

- in line with the size of the enterprises the chance of the awarding is also rising.

- so the longer past an organization has, the bigger the chance of the rewarding, or being rewarded is.

\section{Belonging to a prominence list}

For the question if the organization is belonging to the TOP 500 (or TOP 100) companies in Hungary (or in the county) - which counts as one kind of "independent" key performance indicator, 19 people (12.9\%) gave "yes" as an answer, or "I think so, yes". $79.1 \%$, namely 117 people surely did not belong there, and 12 people declared that they did not know. So, approximately every tenth organization asked got some kind of appreciation, which allow(ed) them to be on some kind of prominence list.

Conclusions:

- the more employees the organization has, the bigger the chance to be on some kind of prominence lists is.

- with the process of aging the rate of belonging to the TOP 500 (or to other TOP-lists) is increasing. 
Table 1

\section{Examination of the correlation in function of the last 5 years awarding, appreciations, rewards $(n=148)$}

\begin{tabular}{|c|c|c|c|c|c|c|c|}
\hline \multicolumn{8}{|c|}{ What kind of awards, appreciations was you/your organization rewarded in the last 5 years? } \\
\hline & $\begin{array}{c}\text { Have not } \\
\text { got }\end{array}$ & $\begin{array}{c}\text { Have got } \\
\text { as a per- } \\
\text { son, from } \\
\text { external } \\
\text { source }\end{array}$ & $\begin{array}{c}\text { Have } \\
\text { got as an } \\
\text { organiza- } \\
\text { tion }\end{array}$ & \begin{tabular}{|c|} 
Have \\
got as a \\
person \\
from the \\
employe- \\
es
\end{tabular} & Total & $\mathbf{p}$ & $\begin{array}{c}\text { Cramer's } \\
\text { V }\end{array}$ \\
\hline \multicolumn{8}{|c|}{ How many employees does your organization have? (including yourself) } \\
\hline 0-9 people & $54 \%$ & $46 \%$ & $13 \%$ & $67 \%$ & $45 \%$ & \multirow[b]{7}{*}{0.024} & \multirow[b]{7}{*}{0.249} \\
\hline 10-49 people & $23 \%$ & $15 \%$ & $20 \%$ & $33 \%$ & $22 \%$ & & \\
\hline 50-249 people & $10 \%$ & $15 \%$ & $30 \%$ & $0 \%$ & $14 \%$ & & \\
\hline 250-500 people & $7 \%$ & $15 \%$ & $10 \%$ & $0 \%$ & $8 \%$ & & \\
\hline 501-1499 people & $3 \%$ & $0 \%$ & $7 \%$ & $0 \%$ & $3 \%$ & & \\
\hline$>1500$ people & $4 \%$ & $8 \%$ & $20 \%$ & $0 \%$ & $7 \%$ & & \\
\hline Total & $100 \%$ & $100 \%$ & $100 \%$ & $100 \%$ & $100 \%$ & & \\
\hline \multicolumn{8}{|l|}{ SME categories } \\
\hline Micro & $54 \%$ & $46 \%$ & $13 \%$ & $67 \%$ & $45 \%$ & \multirow[b]{5}{*}{0.028} & \multirow[b]{5}{*}{0.208} \\
\hline Small & $33 \%$ & $31 \%$ & $53 \%$ & $33 \%$ & $37 \%$ & & \\
\hline Medium-sized enterprises & $6 \%$ & $15 \%$ & $13 \%$ & $0 \%$ & $8 \%$ & & \\
\hline Large company & $7 \%$ & $8 \%$ & $20 \%$ & $0 \%$ & $9 \%$ & & \\
\hline Total & $100 \%$ & $100 \%$ & $100 \%$ & $100 \%$ & $100 \%$ & & \\
\hline \multicolumn{8}{|c|}{ How long has the company (represented by you) been operating? } \\
\hline less than 5 years & $29 \%$ & $0 \%$ & $17 \%$ & $0 \%$ & $24 \%$ & \multirow[b]{6}{*}{0.006} & \multirow[b]{6}{*}{0.249} \\
\hline between $6-10$ years & $19 \%$ & $8 \%$ & $7 \%$ & $33 \%$ & $16 \%$ & & \\
\hline between $11-20$ years & $25 \%$ & $38 \%$ & $13 \%$ & $33 \%$ & $24 \%$ & & \\
\hline between $21-30$ years & $21 \%$ & $23 \%$ & $30 \%$ & $0 \%$ & $22 \%$ & & \\
\hline over 31 years & $7 \%$ & $31 \%$ & $33 \%$ & $33 \%$ & $15 \%$ & & \\
\hline Total & $100 \%$ & $100 \%$ & $100 \%$ & $100 \%$ & $100 \%$ & & \\
\hline \multicolumn{8}{|c|}{ How many is the annual turnover of your company? } \\
\hline under 5 million HUF & $23 \%$ & $0 \%$ & $0 \%$ & $33 \%$ & $16 \%$ & & \\
\hline between 5-10 million HUF & $14 \%$ & $8 \%$ & $3 \%$ & $0 \%$ & $11 \%$ & & \\
\hline between 10-50 million HUF & $17 \%$ & $38 \%$ & $17 \%$ & $67 \%$ & $20 \%$ & & \\
\hline between 50-100 million HUF & $16 \%$ & $8 \%$ & $7 \%$ & $0 \%$ & $13 \%$ & & \\
\hline between 100-500 million HUF & $7 \%$ & $8 \%$ & $3 \%$ & $0 \%$ & $6 \%$ & & \\
\hline between 500 million and 1 billion HUF & $5 \%$ & $8 \%$ & $10 \%$ & $0 \%$ & $6 \%$ & & \\
\hline between 1-5 billion HUF & $7 \%$ & $0 \%$ & $27 \%$ & $0 \%$ & $10 \%$ & & \\
\hline between 5-10 billion HUF & $3 \%$ & $15 \%$ & $0 \%$ & $0 \%$ & $3 \%$ & & \\
\hline over 10 billion HUF & $10 \%$ & $15 \%$ & $33 \%$ & $0 \%$ & $15 \%$ & & \\
\hline Total & $100 \%$ & $100 \%$ & $100 \%$ & $100 \%$ & $100 \%$ & 0.001 & 0.335 \\
\hline
\end{tabular}

\section{The role of export}

In the followings we examined the organizational unobserved latent variables with the context of the export activities, supposing if a company could export their final product, then its performance was over the average on the market anyway. For that question if the organization had any export activity 49 respondents gave yes as an 
answer, so $33.1 \%$ of the examined companies. 91 (61.5\%) companies do not export at all and the number of those who have already started the organizing of the export activities are infinitesimal - 2 companies (1.4\%) have started it and 6 more $(4.1 \%)$ have been thinking about it. Overall we can see, that in the highest turnover categories the export activities are characteristic in any case.

Analysis of the occupied position on the market (positioning)

As an important factor of the excellence, we tried to examine the occupied position on the market with the following question. In the questionnaire we did not give any separated explanation what kind of totality of indices we meant by the answers and because of the diversity of the respondent's professional background, we analysed the ensemble of the three indices in wide interpretation during the connection-examinations. We asked the answer classified in 5 categories, which were as follows (Table 2).

Table 2

Analysis of the occupied position on the market $(n=148)$

\begin{tabular}{|l|c|}
\hline & Distribution, \% \\
\hline We are market leaders with decisive influence & 7.4 \\
\hline We belong to the defining actors & 42.6 \\
\hline Probably average performance is characteristic of us & 40.5 \\
\hline We are lagging. & 5.4 \\
\hline We are loss-making, we are fighting for survival & 4.1 \\
\hline Total & 100.0 \\
\hline
\end{tabular}

Merging the categories, our opinion is that the number of prominently efficient companies is $74(50 \%)$ and the lagging and the loss-making ones are only $14(9.5 \%)$. The leaders of the remaining 60 companies (40.5\%) attributed to their organizations an average performance. The conclusions of the connection-examinations with using unobserved latent variables are:

- the strength of the market position is increasing in line with the number of employees;

- the quantity of the market contest-power is closely related to the size of the company;

- the more heightened the growth rate is, the more the company belongs to the market leaders, or to the defining actors - and reverse.

- all in all, those whose annual turnover is over 500 million HUF, represent bigger rate between the excellencies (market leaders and defining organizations).

\section{Opportunities and limitations of personal leadership}

\section{Size of the organization}

Despite the national economic importance of the smaller companies, they are still lagging behind the large companies concerning the aspects of quality and excellence - according to research (Demirbag et al., 2006; Herzallah et al., 2014; Sternad et al., 2017). 
The reason for this, according to Sternad et al. (2017), is that the SMEs still hesitate to consider comprehensive managerial systems, which help to monitor the quality and support the organizational and managerial excellence, because of their limited financial, time and human resources. The lack of awareness and understanding contribute to this, as well as the attitudes of the leaders and the concept fears, too - according to Murphy and Leonard (2016).

In the questionnaire we asked the question: how much do they think themselves excellent on a 1-5 Likert scale? The average was 3,9 (the standard distribution $=0.754$ ), so the respondents find themselves capable of being a leader, but only $16.2 \%$ qualified themselves as excellent. On Figure 1 it can be seen that the leaders of medium-sized and large enterprises find themselves excellent, as long as the leaders of small and micro-sized enterprises find themselves excellent to a much smaller rate.

\section{Figure 1}

Managerial excellence depending on the size of the organization ( $n=148)$

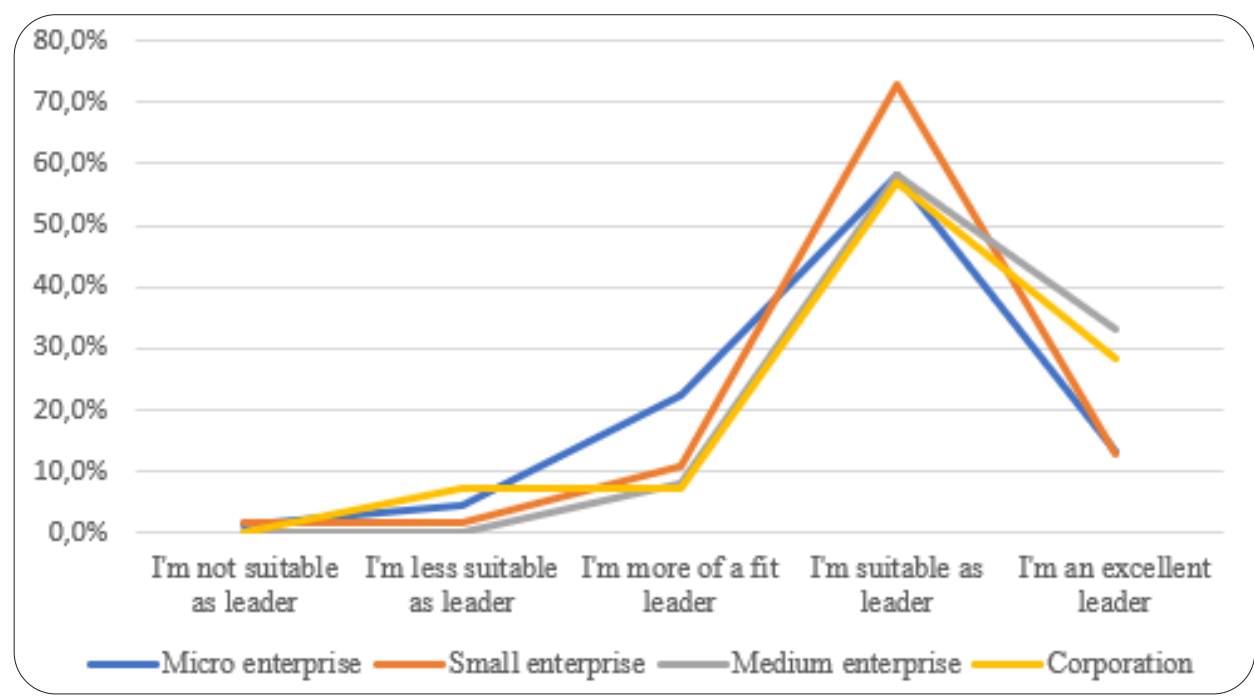

We can conclude from this the following: the micro- and small-sized enterprises have real backwardness in the field of management compared to the multinational companies. The reasons which lead to this would be worth examining, henceforth directed help, consultation could be provided for the leaders of micro- and small-sized enterprises in order to develop their efficiency, because they have significant impact on every country's national economy. It causes more difficulties that only 10-15 percent of the leaders receive training and even fewer of them (5-10\%) avail themselves of coaching. It would be suggested to support the trainings centrally, the leading development programs and to share the good practices in wider circles for free. As in qualification they do not have any backwardness in proportion to the leaders of large companies, further education and adult education could be suggested, too. 


\section{Level of the profit}

Comparing the claim how much the leaders think themselves excellent with the profit, the growth-rate and the market influence, we are able to draw more conclusions. We discovered that it showed significant connection with the profit $(\mathrm{n}=148$, $\mathrm{p}=0.001$, Cramer $=0.354$ ). It means, that $17.54 \%$ of the leaders of the long-term profitable organizations describe themselves as an excellent leader; $65.78 \%$ of them as absolutely competent and there is no one, who find themselves less competent or incompetent. The leaders of the non-profitable companies gave the following answers for this question: $20.54 \%$ of them do not, $55.88 \%$ of them find themselves ,just" competent to be a leader.

\section{Growth rate}

Although the examination does not show any significant correlation between the growth rate and the managerial competence, the results are informative. All the leaders of the „rocket-mode soaring” companies find themselves competent to be a leader, respectively the excellent ones. The leaders of those companies which are growing significantly gave similar answers, only $3 \%$ of them do not find themselves competent to be a leader. In the "stagnant" and "decreasing" categories the rate is much smaller: in case of the stagnant companies $13.51 \%$ of the leaders, in case of the decreasing companies none of them think themselves to be an excellent leader. $36.36 \%$ of the leaders of the market leader companies find themselves excellent, $54.54 \%$ of them find themselves competent to be a leader and there is no one who would find him/ herself less competent or incompetent.

The rate is similar in case of the defining market actors. The results are well demonstrated on Figure 2:

\section{Figure 2}

Market influence depending on managerial adequacy $(n=148)$

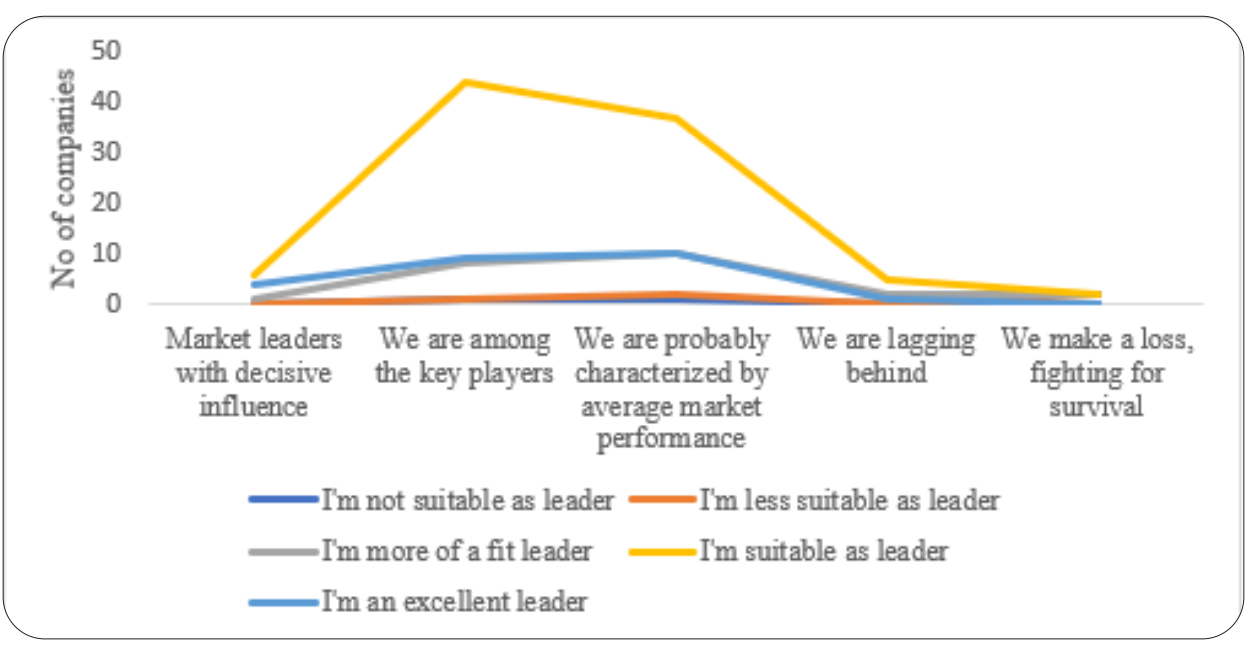


One of my personal observation, based on these results, is that the self-assessment of the leaders is still fairly low, which is a very important element of emotional intelligence. An emotionally intelligent leader has high-level self-knowledge, which includes self-assessment, too. Those leaders who lead permanently profitable or „,rocket-mode soaring" companies, should see themselves as excellent leaders, but somehow - according to their self-assessment, they do not. All in all, there is significant correlation between the measurement tools of excellence and managerial excellence, although, the tightness of it is low or medium strong based on this sample.

\section{Experiential years as a leader}

There is not any significant correlation between managerial excellence and the number of experiential years as a leader based on this research. In my humble opinion is that it is thanks to the fact that the younger, less experienced leaders have higher self-assessment, and the excellent qualified companies' leaders were conservatively in this topic respectively.

\section{Other cases from the other parts of the original survey}

We have found important connections related to the managerial excellence in three other cases, depending on the company size.

- it is less characteristic of the large companies to focus only on the results, without considering the efforts. $(n=148, p=0.030$, Cramer $=0.229)$, but it is very characteristic of the micro-enterprises;

- proportionate to the company size the number of those leaders increases, who ask for continuous feedback from their subordinates about themselves as leaders. $(\mathrm{n}=148, \mathrm{p}=0.000$, Cramer $=0.249)$;

- proportionate to the company size the time spent in the 3. time managerial quarter - the quarter of the urgent, but not important activities decrease. $(n=148$, $\mathrm{p}=0.022$, Cramer $=0.426$ )

- In one case, we have found important connection depending on the number of employees. Depending on the increase of the number of the employees the rate of those leaders increases, who ask for continuous feedback from their subordinates about themselves as leaders. $(\mathrm{n}=148, \mathrm{p}=0.050$, Cramer $=0.277)$

\section{CONCLUSIONS AND LIMITATION OF THE RESEARCH}

The comparisons with the applied independent(market) key performance indicators to the measuring of the organizational excellence brought the following results (Table 3).

As it can be seen, significant correlation can be found in case of three variables from the six, regarding the mentioned unobserved latent variables - appreciations, to be awarded, to be on a TOP-list and market influence. The export, the growth rate and the profitability are not dependent on the company size or on the number of the employees. 
Table 3

\section{Examination of the organizational excellence depending on the company size and the number of employees $(n=148)$}

\begin{tabular}{|c|c|c|}
\hline Variable & $\begin{array}{l}\text { Company size according to the } \\
\text { SME categories }\end{array}$ & Number of the employees \\
\hline Awards, appreciations & $\begin{array}{l}\text { Generally, the most awarded } \\
\text { was the micro and then small } \\
\text { enterprises. They have got } \\
\text { mostly personal appreciations } \\
\text { from the employees, while the } \\
\text { medium-sized enterprises and } \\
\text { large companies have got as an } \\
\text { organization, and personal app- } \\
\text { reciations from external sources. } \\
(\mathrm{n}=148, \mathrm{p}=0.028 \text {, } \\
\text { Cramer }=0.208)\end{array}$ & $\begin{array}{l}\text { Significant correlation can be found } \\
\text { in the examination according to the } \\
\text { number of the employees, and simi- } \\
\text { larly according to the company size. } \\
(\mathrm{n}=148, \mathrm{p}=0.024 \text {, Cramer }=0.249) \text {. } \\
\text { As we can see, the most awarded } \\
\text { people are in those companies, whe- } \\
\text { re the number of the employees was } \\
\text { under } 9 \text { people, which was followed } \\
\text { by the } 10-49 \text { category. }\end{array}$ \\
\hline Export & No significant correlation & No significant correlation \\
\hline TOP-list & $\begin{array}{l}\text { Primarily the large compa- } \\
\text { nies and the medium-sized } \\
\text { enterprises belong to the } \\
\text { TOP-list companies. Our } \\
\text { examination showed significant } \\
\text { correlation between the two } \\
\text { variables. }(\mathrm{n}=148, \mathrm{P}=0.000 \text {, } \\
\text { Cramer }=0.375)\end{array}$ & $\begin{array}{l}81,82 \% \text { of those companies which } \\
\text { have more than } 1500 \text { employees are } \\
\text { on a TOP-list and it is decreasing } \\
\text { in proportion to the number of the } \\
\text { employees. } \\
(\mathrm{n}=148, \mathrm{p}=0.000, \text { Cramer }=0.431)\end{array}$ \\
\hline Market influence & $\begin{array}{l}\text { According to our examination, } \\
\text { the market influence is increa- } \\
\text { sing in proportion to the size of } \\
\text { the company. } \\
(\mathrm{n}=148, \mathrm{p}=0.000 \\
\text { Cramer }=0.312)\end{array}$ & $\begin{array}{l}100 \% \text { of those companies which } \\
\text { have more than } 1500 \text { employees are } \\
\text { market influencers, and it is decrea- } \\
\text { sing in proportion to the decreasing } \\
\text { number of employees. } \\
(\mathrm{n}=148, \mathrm{p}=0.000 \text {, Cramer }=0.314)\end{array}$ \\
\hline Growth rate & No significant correlation & No significant correlation \\
\hline Profitability & No significant correlation & No significant correlation \\
\hline
\end{tabular}

We can conclude from this the following: the micro- and small-sized enterprises have real backwardness in the field of management in proportion to the multinational companies.

As we could see in the examinations of the correlations between the examined variables, the Cramer's V contingency coefficient test showed mostly a moderate association, a strong relationship, the value being around 0.3 . In the future it may be worthwhile to involve data mining, with bicluster procedure in the $\mathrm{R}$ program.

The limitation of this research is that it is a small, not representative sample, based on the national data from 2018, our sample of 148 covers $2.01 \%$ of Hungarian corporates based on the number of staff (basic population = 3121 thousand people, $K S H, 2018)$. Instead, small businesses and large corporations are relatively overrepresented to national data. 
In this way the result cannot be generalized, but can be a good foundation for further, national level research and represents progress in the field, because we have succeeded in validating some new independent variables which could measure organizational excellence.

\section{ACKNOWLEDGMENT}

This publication has been written by "Excellence in Leadership and Management" and "HumanagementHuman Value" research groups as founders of the Leader's Habits Network-leadershabits.com.

The research is carried out by EFOP-3.6.1-16-2016-00007. It was supported by the Intelligent Specialization Program at the University of Kaposvár.

\section{REFERENCES}

Atkinson, A. (1998). Strategic performance measurement and incentive compensation. European Management Journal, 16(5), 552-561.

Bányai, E., \& Sipos, N. (2019). Aktualitások a felsővezetői kiválóság területén. Vezetéstudomány, 50(1), 63-69. https://doi.org/10.14267/VEZTUD.2019.01.06

Berke, S. (2019). Kiváló vezető, kiváló vállalkozás - kutatás a stratégiai szemléletú vezetésről. https://www.hrportal.hu/hr/kivalo-vezeto--kivalo-vallalkozas---kutatas-a-strategiai-szemleletu-vezetesrol-20190806.html

Bódi-Schubert, A. (2012). A siker szerepe és jelentése a vevő-beszállító kapcsolatban. Vezetéstudomány, 43(11), 46-59. https:/doi.org/10.14267/VEZTUD.2012.11.04

Böcskei, E., \& Fekete, H. (2012). A vállalati teljesítmény mérése az elmúlt évtized tükrében - a teljesítménymenedzsment szerepe. A controller, 8(1), 1-6.

Chikán, A., \& Czakó, E. (2009). Versenyben a világgal - Vállalataink versenyképessége az új évezred küszöbén. Akadémiai Kiadó, Budapest

Cho, J., \& Dansereau, F. (2010). Are transformational leaders fair? A multi-level study of transformational leadership, justice perceptions and organizational citizenship behaviours. The Leadership Quarterly, 21 (3), 409-421. https:doi.or$\mathrm{g} / 10.1016 / \mathrm{j}$.leaqua.2010.03.006

Cole, N. (2017). The 4 fundamental pillars of a successful company according to these 4 ceos. https://www.inc.com/nicolas-cole/the-4-fundamental-pillars-of-asuccessful-company-according-to-these-4-ceos.html

Dajnoki, K., \& István, K. A. (2020). Bevezetés az emberi erőforrás menedzsmentbe. 129 p. Debreceni Egyetem, Debrecen

Dalglish, C. (2004). Business Success and Sustainability. Proceedings International Council for Small Business Conference, 48, 1-11. ICSB, Johannesburg https:// eprints.qut.edu.au/2634/

David, F. (2011). Strategic Management: Concept and cases. Prentice Hall, New Jersey 
Demirbag, M., Tatoglu, E., Tekinkus, M., \& Zaim, S. (2006). An analysis of the relationship between TQM implementation and organizational performance: Evidence from Turkish SMEs. Journal of Manufacturing Technology Management, 17(6), 829-847.

Dobák, M. (2008). Szervezeti formák és vezetés. Akadémiai Kiadó, Budapest

Donaldson, T., \& Preston, L. (1995). The Stakeholder Theory of the Corporation: Concepts, Evidence and Implications. The Management Review, 20(1), 65-91.

Gates, S. (1999). Aligning Strategic Performance Measures and Results. The Conference Board, Canada

Getz, D., \& Carlsen, J. (2000). Characteristics and goals of family and owner-operated businesses in the rural tourism and owner-operated businesses in the rural torism and hospitality sectors. Tourism Management, 21(6), 547-560. https:// doi.org/10.1016/S0261-5177(00)00004-2

Herzallah, A. M., Gutierrez-Gutierrez, L., \& Munoz Rosas, J. F. (2014). Total quality management practices, competitive strategies and financial performance: The case of the Palestinian industrial SMEs. Total Quality Management \& Business Excellence, 25(5-6), 635-649. https://doi.org/10.1080/14783363.2013.824714

Howard, J. L. (2006). Small business growth: Development of indicators. Academy of Entrepreneurship Journal, 12(1), 73-88.

IMD. (2012). World Competitiveness Yearbook. Institut for Management Development, Lausanne

Ittner, C., Larcker, D., \& Randall, T. (2003). Performance implications of strategic performance measurement in financial services firms. Accounting, Organizations and Society, 28(7-8), 715-741. https://doi.org/10.1016/S0361-3682(03)00033-3

Kaplan, R., \& Johnson, H. (1987). Relevance Lost: The Rise and Fall of Management Accounting. Harward Business School Press, London

Kemény, I. (2015). A versenytársak csak egy kattintásra vannak. Budapest: Corvinus Egyetem. Doctoral (PhD) Dissertation, Budapesti Corvinus Egyetem, Gazdálkodástani Doktori Iskola. https://doi.org/10.14267/phd.2015030

Kerepesi, K. (2009). Versenyképes vállalat-megfelelő finanszírozás. A magyar kkv-k vizsgálata. In Márkus, Gy. (ed.) Tudástársadalom, vállalkozás, Európa. 35-44. Általános Vállalkozási Főiskola, Budapest

Kollár P., Szabó K. (2019). Az átalakító vezetés komponensei, In Köszegi, I. R. (ed.) III. Gazdálkodás és Menedzsment Tudományos Konferencia, 1176-1182. Neumann János Egyetem, Kecskemét

Kőmüves Zs., Szabó-Szentgróti G., Bence-Kiss K. (2018). Leadership Anomalies Caused by Scarce Workforce. In Csata, A., Pop, G., Fejér-Király, G., Kassay, J., Nagy, B., Zsarnóczky, M., Pál, L. (eds.) $14^{\text {th }}$ Annual International Conference on Economics and Business: Challenges in the Carpathian Basin: Innovation and technology in the knowledge based economy. (pp. 358-368.) Sapientia Hungarian University of Transylvania, Miercurea Ciuc, Romania

Lázár, E. (2009). Kutatásmódszertan a gyakorlatban az SPSS program használatával. Sci-entia Kiadó, Cluj-Napoca, Romania 
Lorino, P., \& Gehrke, I. (2007). Coupling Performance Measurement and Collective Activity: The Semiotic Function of Management Systems. A Case Study. ESSEC Centre de Recherche, France

Majoros, P. (2010). A kutatásmódszertan alapjai: tanácsok, tippek, trükkök nem csak szakdolgozat-íróknak. Perfekt, Budapest

Murphy, W. H., \& Leonard, D. (2016). Quality Management (QM) leads to healthier small businesses. Journal os Small Business and Enterprise Development, 23(4), 1104-1119. https:/doi.org/10.1108/JSBED-12-2015-0169

Neely, A. (1998). Measuring Business Performance: Why, What and How. The Economist and Profile Books Ltd., London

Neely, A., Adams, C., \& Kennerly, M. (2004). Teljesítményprizma. Alinea, Budapest

Neely, A., Gregory, M., \& Platts, K. (1995). Performance ManagementSystem Design-ALiterature Review and Research Agenda. International Journal os Operations \& Production Management, 15(4), 80-116. https://doi.org/10.1108/01443579510083622

Némethné Pál, K., \& Papanek, G. (2014). Kisvállalati siker a nemzetközi szakirodalomban. GKI, Budapest https://www.gki.hu/wp-content/uploads/gki/szakirodalom_1404.pdf

Pató GábornéSzűcs, B., \& Illés, K. (2018). Az emberközpontú munkaköri leírás. Hadtudomány, 28(2), 107-117. https://doi.org/10.17047/HADTUD.2018.28.2.107

Pierog, A., Bácsné, Bába É., Dajnoki, K. (2017). Sikeres vezetők tulajdonságainak feltárása a Debreceni Egyetem Gazdaságtudományi Kar hallgatói körében végzett kutatás eredményei alapján. Taylor: Gazdálkodás- és Szervezéstudományi Folyóirat, 9(1), 94-100.

Porter, M. E. (2006). Versenystratégia. Akadémiai Kiadó, Budapest

Porter, M. E. (2008). The Five Competitive Forces that Shape Strategy. Harvard Business Review, (1), 86-104.

Porter, M. E. (2008). The Five Competitive Forces that Shape Strategy. Special Issue on HBS Centennial. Harvard Business Review, 86(1), 78-93.

Rappaport, A. (1983). Corporate performance standards and shareholder value. The Journal os Business Strategy, 3(4), 28-38.

Rappaport, A. (1999). Creating Shareholder Value. The Free Press, New York

Ridley, M. (2012). A józan optimista. Akadémiai Kiadó, Budapest

Sinek, S. (2019). Kezdj a miérttel! Az inspiráló vezetés titka. HVG, Budapest

Sternad, D., Krenn, M., \& Schmid, S. (2017). Business excellence for SMEs: motives, obstacles, and size-related adaptations. Total Quality Management \& Business Excellence, 30(1-2), 151-168. https://doi.org//10.1080/14783363.2017.1300054

Szűts, I. (1983). Módszerek a vállalati hatékonyság átfogó elemzéséhez. Közgazdasági és Jogi Könyvkiadó, Budapest

Tomal, D. R., \& Jones, K. J. (2015). A comparison of core competencies of women and men leaders in the manufacturing industry. The Coastal Business Journal, $14(1), 13-25$.

Walker, E., \& Brown, A. (2004). Whats success factors are important to samll business owners? International Small Business Journal, 22(6), 577-594. 
Wimmer, Á. (2002). Üzleti teljesítménymérés. Mühelytanulmányok, 17, 1-48. http://edok.lib.uni-corvinus.hu/35/1/Wimmer17.pdf

Zsidó, K., \& Fenyves, V. (2015). Application of „Traditional” and „New” approach methods in Business Performance Measuerement. Cross-Cultural Management Journal, 17(1), 51-57.

Corresponding author:

\section{Erzsébet Gyopár CsaPAI}

Szent István University Kaposvár Campus

Doctoral School for Management and Organizational Science

H-7400 Kaposvár, Guba Sándor u. 40.

e-mail: csapai.gyopar@gmail.com

(C) Copyright 2020 by the authors.

This is an open access article under the terms and conditions of the Creative Commons attribution (CC-BY-NC-ND) license 4.0.

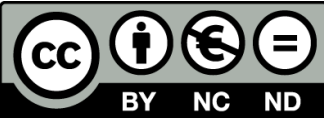

